\title{
Zinc Finger Protein 217
}

National Cancer Institute

\section{Source}

National Cancer Institute. Zinc Finger Protein 217. NCI Thesaurus. Code C21458.

Zinc finger protein 217 (1048 aa, 115 kDa) is encoded by the human ZNF217 gene. This protein plays a role in the negative regulation of transcription. 